\title{
Recent studies on molecular mechanisms involved in mammalian sperm capacitation: A review
}

\author{
L. Kątska-Książkiewicz ${ }^{1}$ \\ Department of Bioengineering, Faculty of Biotechnology, Rzeszów University \\ 36-100 Kolbuszowa, Poland
}

(Received 20 February 2007; revised version 24 April 2007; accepted 6 September 2007)

\begin{abstract}
Sperm capacitation is a physiological event that allows sperm to bind and fuse with the oocyte. Changes associated with this process include removal of cholesterol from the plasma membrane, increases in $\mathrm{pH}$ and $\mathrm{Ca}^{+2}$, activation of first and second messenger cascades, an increase in respiration and subsequent changes in the sperm motility pattern. The most significant change in sperm after capacitation is its ability to undergo the acrosome reaction. The purpose of this review is to present some recent achievements towards understanding the molecular mechanisms of mammalian sperm capacitation. The review focuses on regulation of sperm function by seminal plasma derived first messengers, i.e. fertilizationpromoting peptide (FPP), adenosine, calcitonin and angiotensin II, acting to affect production of a second messenger, cAMP. It also discusses the roles in sperm capacitation of speradhesins, platelet-activating factor (PAF) and PAF-acetylhydrolase, roles of $\mathrm{Ca}^{+2}$ ions, bicarbonate ions, and intracellular $\mathrm{pH}$, roles of calmodulin and 1, 4, 5-triphosphate ( $\left.\mathrm{IP}_{3}\right)$, protein tyrosine phosphorylation and actin polymerization, protein translation as well as hyperactivation and acrosome reaction as a final step of capacitation.
\end{abstract}

KEY WORDS: mammalian sperm, capacitation, acrosomal reaction, molecular mechanisms

\section{INTRODUCTION}

Mammalian spermatozoa must undergo several steps of extra-testicular maturation to be able to fertilize oocytes. They are transported from the testes through the ductus epididymides to be stored in the epididymal tail. The first

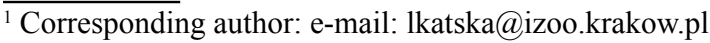


step of that long maturational process takes place in the epididymis, where spermatozoa acquire the potential for motility. At ejaculation, they are transported along the internal genitalia becoming motile and conditioned by constituents of seminal fluid. However, it has been known for over 50 years that immediately after ejaculation spermatozoa are not able to fertilize oocytes. These properties were discovered at that time by Austin (1951) and

Chang (1951) and described as "an obligate period of residence of the spermatozoon in the female reproductive tract during which it acquires the ability to fertilize the oocyte". Indeed, during migration through the female genital tract, spermatozoa continue a process of extra-testicular maturation called capacitation, because following it, they have the capacity to fertilize oocytes. Although several hypotheses have been developed, and remarkable progress has been made in understanding the molecular mechanisms involved in the process of capacitation, not all mechanisms are well understood.

The process of capacitation consists of a series of biochemical and membranous modifications preparing the spermatozoa first for the acrosome reaction and then for fertilization. This process include, among others, changes in lipid composition, surface properties, fluidity, permeability to $\mathrm{Ca}^{+2}$, removal of cholesterol from the plasma membrane, increases in $\mathrm{pH}$, activation of second messenger cascades, an increase in respiration and subsequent changes in the sperm motility pattern (de Lamirade et al., 1997; Darszon et al., 2001; Suarez and Ho, 2003; Felix, 2005).

A simplified working model of capacitation of mammalian spermatozoa was reviewed by the author a few years ago (Katska, 2000). It was described that cholesterol removal from the plasma membrane of spermatozoon changes the membrane fluidity, which, in turn, affects the influx of certain ions such as $\mathrm{HCO}_{3}^{-}$ and $\mathrm{Ca}^{+2}$. This is followed by the stimulation of adenyl cyclase (AC), which increases the intracellular cAMP level in spermatozoa. cAMP activates protein kinase A, which directly or indirectly influences the activities of protein tyrosine kinase and/or phoshatase, finally increasing the protein tyrosine phosphorylation. Several signaling molecules such as protein kinase C, phosphodiesterase (PDE) and other kinases and phosphatases are also involved in the signaling network.

The purpose of this review is to present some recent achievements towards understanding the molecular mechanisms of mammalian sperm capacitation. The review focuses on regulation of sperm function by seminal plasma derived first messengers, i.e. fertilization-promoting peptide (FPP), adenosine, calcitonin and angiotensin II, acting to affect production of a second messenger, cAMP. It also discusses the roles in sperm capacitation of speradhesins, platelet-activating factor (PAF) and PAF-acetylhydrolase, roles of $\mathrm{Ca}^{+2}$ ions, bicarbonate ions, and intracellular $\mathrm{pH}$, roles of calmodulin and 1, 4, 5-triphosphate $\left(\mathrm{IP}_{3}\right)$, protein tyrosine phosphorylation and actin polymerization, protein translation as well as hyperactivation and acrosome reaction as a final step of capacitation. 


\section{ENDOGENOUS EXTRACELLULAR REGULATION OF SPERM FUNCTION}

Capacitation needs to be regulated to provide maintenance of sperm fertilizing potential. Seminal plasma contains several proteins known as "first messengers" that bind to the specific receptors on the sperm surface, thereby activating/regulating important intracellular signaling pathways and hence modulating capacitation (Fraser et al., 2005, 2006). These molecules initially accelerate capacitation and then inhibit spontaneous acrosome loss acting as first messenger to affect production of the second messenger, cAMP, by membrane-associated adenyl cyclases (mACs), in G-protein-regulated way (Fraser et al., 2005). These seminal plasma derived first messengers include fertilization-promoting peptide (FPP), adenosine, calcitonin and angiotensin II (Fraser, 1998; Fraser et al., 2005, 2006). The first messengers initially stimulate cAMP production through modulation of adenyl cyclase (AC) activity and so accelerate capacitation. The same molecules then inhibit cAMP production and also inhibit spontaneous acrosome reaction (Fraser et al., 2003, 2005). In addition, both adenosine and calcitonin are known to be present in general body fluids (Fraser et al., 2003).

\section{Role of $G$ protein receptors in mammalian sperm capacitation}

Receptors of adenosine and calcitonin belong to the $\mathrm{G}$ protein coupled receptor (GPCR) family. The FPP receptor-TCP11, lacks transmembrane regions and cannot directly regulate AC. It interacts with adenosine receptors. This is in contrast to the situation in somatic cells, which possess G protein-coupled receptors with seven transmembrane regions (Adeoya-Osiguwa et al., 1998). Spermatozoa have two populations of adenosine receptors, stimulatory $A_{2 A}$ and inhibitory $A_{1}$. The former are active only in uncapacitated sperm and the latter only in capacitated sperm (Adeoya-Osiguwa and Fraser, 2002). At the start of capacitation only the $\mathrm{A}_{2 \mathrm{~A}}$ receptors appear to be functional since agonists and antagonists specific for the $A_{1}$ receptors have no effect on uncapacitated spermatozoa, while in capacitated spermatozoa only $\mathrm{A}_{1}$ receptors appear to be active and $\mathrm{A}_{2 \mathrm{~A}}$ agonists and antagonists have no effect (Adeoya-Osiguwa and Fraser, 2002).

Adenosine stimulates AC/cAMP in uncapacitated sperm and inhibits $\mathrm{AC} /$ cAMP in capacitated sperm (Adeoya-Osiguwa and Fraser, 2002). This is the same response as FPP. Moreover, FPP + adenosine produce a greater response than either used alone, suggesting that these two may work on the same signal transduction pathway (Fraser et al., 2005). Calcitonin receptors are present in only one population which regulates $\mathrm{mAC} / \mathrm{cAMP}$, as do FPP and adenosine (AdeoyaOsiguwa and Fraser, 2003; Fraser et al., 2005, 2006).

Recent investigations on $G$ proteins in mammalian spermatozoa have demonstrated the presence of both stimulatory (Gas) and inhibitory (Gai) subunits 
in sperm membranes and intact spermatozoa (Baxendale and Fraser, 2003). The first messengers, GPCRs and G proteins consist of typical signal transduction pathways, but functioning pathways also have a target protein, the function of which is altered by the activation of the receptors and G proteins (Fraser et al., 2005). Considering that first messengers regulate cAMP production this target protein should be mAC isoform (Fraser et al., 2005). Electrophoresis/Western blotting using mouse sperm membranes and homogenates and immunolocalization using whole cells revealed the presence of several mACs; as it was suggested by Fraser et al. (2005) these isoforms in mature spermatozoa are modified versions of the proteins found in somatic cells. However, the specific functions of these isoforms within spermatozoa are unknown at present (Fraser et al., 2006).

\section{Role of angiotensin II in capacitation}

Seminal plasma contains another peptide included in the first messengers, angiotensin II (AII). Unlike FPP/adenosine/calcitonin that regulate capacitation, AII accelerates capacitation in uncapacitated spermatozoa but has no inhibitory effect on spontaneous acrosome reaction in capacitated sperm (Fraser and Osiguwa, 2004; Fraser et al., 2005). The combination of low concentration of AII with either low calcitonin or FPP or both resulted in significant acceleration of capacitation, suggesting that all three peptides act on the same or related signal transduction pathways (Fraser et al., 2005, 2006). It has been shown that binding of AII to its receptor stimulates cAMP in both uncapacitated and capacitated spermatozoa (Mededovic and Fraser, 2004) possibly by altering intracellular $\mathrm{Ca}^{2+}$ concentration (Mededovic and Fraser, 2005).

\section{Role of spermadhesins in capacitation}

Seminal plasma of pig, horse, bull and also human contains secretory proteins that belong to the spermadhesin protein family (Töpfer-Petersen et al., 1998; Kraus et al., 2005). In the pig the most ( $>90 \%)$ of the seminal plasma proteins belong to this family (Töpfer-Petersen et al., 1998). The family comprises five members (AQN-1, AQN-3, AWN, PSP-I, and PSP-II). Sequence variations, glycosylation, and the aggregation state of spermadhesins contribute to their distinct biological activities (Calvete et al., 1993, 1995a,b,c; Nimtz et al., 1999). Spermadhesins AQN-1, AQN-3, and AWN are heparin-binding and sperm-coating molecules that appear to stabilize the plasma membrane over the acrosomal vesicle and are mainly released during capacitation (Sanz et al., 1993; Dostàlova et al., 1994; Calvete et al., 1997). AQN-3 forms part of a sperm motility-inhibitor factor complex (Iwamoto et al., 1995). AQN-1 and AWN are sperm-associated acrosin-inhibitor acceptor proteins (Sanz et al., 1992). AWN has been characterized as a sperm 
surface-associated lectin thought to mediate sperm-zona pellucida interactions at fertilization (Calvete et al., 1995c; Rodriguez-Martinez et al., 1998).

Role of platelet-activating factor (PAF) and PAF-acetylhydrolase (PAF-AH) in sperm capacitation

The functions of PAF and PAF-AH have been reviewed in details by Kordan et al. (2003) and more recently by Roudebush (2007). The PAF is a potent signaling phospholipid (1-O-alkyl-2-acetyl-sn-glycero3-phosphorylcholine) found in the sperm of many laboratory and livestock species as well as in human. The primary biological effect of PAF binding to target cells is an increase in phosphatidylinositol 4,5-biphosphate $\left(\mathrm{PIP}_{2}\right)$ breakdown and the subsequent formation of diacylglycerol (DAG) and inositol 1,4,5,-triphoshate $\left(\mathrm{IP}_{3}\right)$ in the spermatozoa, resulting in calcium mobilization (Kordan et al., 2003). Such an increase in intracellular calcium as a result of PAF action on the sperm cells is necessary for hyperactivation of sperm motility during capacitation (Ricker et al., 1989). However, in the opinion of Roudebush (2007) the exact mechanism for PAF as it relates to sperm function is unclear, although its importance is substantial. PAF appears to be critical for many events surrounding fertilization, early embryo development, implantation as well as sperm capacitation (Kumar et al., 1988; Kuzan et al., 1990; Parks et al., 1990; Roudebush and Diehl, 2001; Kordan et al., 2003; Roudenbush, 2007). PAF is synthesized, metabolized, and used by sperm - it may in fact be one biomarker for sperm capacitation (Roudebush, 2007), while PAF-AH is qualified to be a candidate for sperm decapacitation factors (Zhu et al., 2006b; Roudebush, 2007). The data confirmed that PAF-AH is significantly and negatively correlated with sperm motility (Zhu et al., 2006b). Removal of this enzyme during capacitation promotes PAF synthesis increasing sperm motility and fertilization (Roudebush, 2007). It is hypothesized that PAF-AH which originates from the epididymis and other accessory sexual glands may be a causative factor of male infertility (Zhu et al., 2006a).

\section{Role of $\mathrm{CA}^{+2}$ ions}

Calcium is known to affect various functions of spermatozoa such as motility, capacitation and fertilizing ability. Elevation of calcium in the flagellum of spermatozoon drives hyperactivation (Ho and Suarez, 2001). Investigations on spermatozoa from many mammalian species have shown that $\mathrm{Ca}^{+2}$ ions are required for capacitation (de Lamirande et al., 1997). $\mathrm{Ca}^{+2}$ ions have been shown to be increased during capacitation. This may be the result of reduced $\mathrm{Ca}^{+2}$ efflux due to inhibition of the $\mathrm{Ca}^{+2}$ ATPase pump, increased leakage of $\mathrm{Ca}^{+2}$ across the membrane due to instability caused by removal of cholesterol, and/or increased 
$\mathrm{Ca}^{+2}$ influx due to the activation of unidentified channels (Jagannathan et al., 2002; Felix, 2005). In the plasma membrane and in the acrosome membrane of mammalian sperm there are identified and characterized multiple $\mathrm{Ca}^{+2}$ permeable channels. Voltage-gated $\mathrm{Ca}^{+2}\left(\mathrm{Ca}_{\mathrm{v}}\right)$ channels are transmembrane proteins that are open in response to membrane depolarization and allow $\mathrm{Ca}^{+2}$ ions to enter the cell from the extracellular space (Felix, 2005). Channels $\mathrm{Ca}_{\mathrm{v}}$ have been subdivided according to their electrophysiological and pharmacological properties into low voltage activated (LVA or T-type) channels, and high-voltage activated (HVA) channels (Felix, 2005). There is evidence suggesting that T-type $\mathrm{Ca}_{\mathrm{v}}$ channels, through their window current, might contribute to setting $\mathrm{Ca}^{+2}$ ions at the resting potential and therefore influence sperm capacitation (Felix, 2005). In spermatogenic cells, serum albumin induces an increase in $\mathrm{Ca}^{+2}$ window current by shifting the voltage dependence of both steady-state activation and inactivation of T-type $\mathrm{Ca}_{v}$ channels (Espinosa et al., 2000). As there is evidence that these channels are present in mature sperm (Jagannathan et al., 2002), serum albumin might facilitate an increase in $\mathrm{Ca}^{+2}$ entry, a prerequisite to capacitation (Felix, 2005). Another potential mechanism for regulation of $\mathrm{Ca}_{\mathrm{v}}$ channels during sperm capacitation includes phosphorylation (Felix, 2005). The capacitation process has been correlated with increased tyrosine phosphorylation as a subset of sperm proteins (Ficarro et al., 2003).

The amount of extracellular $\mathrm{Ca}^{+2}$ required to obtain biologically detectable responses differ among the first messenger peptides. Although FPP can bind to spermatozoa in $\mathrm{Ca}^{+2}$ deficient medium, it requires at least $90 \mu \mathrm{M}$ of $\mathrm{Ca}^{+2}$ to stimulate capacitation (Green et al., 1996). In contrast, calcitonin can stimulate cAMP production and capacitation in presence of trace amounts of $\mathrm{Ca}^{+2}$ in medium (Adeoya-Osiguwa and Fraser, 2003). The explanation for these differences in the $\mathrm{Ca}^{+2}$ requirements of FPP and calcitonin is that each first messenger is regulated by different $\mathrm{mAC}$ isoforms. This is plausible since $\mathrm{mAC}$ isoforms are known to differ in their $\mathrm{Ca}^{+2}$ requirements (Defer et al., 2000; Fraser et al., 2005). Other enzymes present in spermatozoa, such as phospholipase $\mathrm{A}_{2}$ and protein kinase $\mathrm{C}$, are also dependent on the presence of calcium (Yanagimachi, 1994; Doherty et al., 1995; Felix, 2005).

\section{Role of calmodulin and 1,4,5-triphosphate $\left(\mathrm{IP}_{3}\right)$ during intracellular $\mathrm{Ca}^{+2}$ moblilization}

As it has been already mentioned, $\mathrm{Ca}^{+2}$ ions have been suggested to play a key role in maintenance of motility. They can bind to calmodulin (CaM, a 17 $\mathrm{kDa} \mathrm{Ca}{ }^{+2}$-binding protein) and this complex regulates the activity of multiple enzymes, including $\mathrm{Ca}^{+2} /$ calmodulin-dependent protein kinases (CaM kinases). Immunological studies have shown that $\mathrm{Ca}^{+2} /$ calmodulin-dependent protein kinase 
IV (CaMKIV) is present and localizes to the human sperm flagellum. Activity of CaMKIV increases during sperm capacitation (Bendahmane et al., 2001; MarinBriggiler et al., 2005). In pig, calmodulin dependent protein kinase II (CaMKII) is involved in the capacitation and acrosome reaction of spermatozoa (Ito et al., 2004).

It has been shown that inclusion of purified $\mathrm{CaM}$ in the capacitation medium stimulates adenyl cyclase, which in turn increases the levels of cAMP and, in consequence, significantly increased tyrosine phosphorylation of $82 \mathrm{kDa}$ and 95 $\mathrm{kDa}$ sperm molecules (Zeng and Tulsiani, 2003). It has been demonstrated by Zeng and Tulsiani (2003) that several CaM antagonists prevented sperm capacitation in mouse, as demonstrated by their diminished ability to undergo agonist-induced acrosome reaction and their actions took place either with or without adverse effects on sperm motility and protein tyrosine phosphorylation.

Inositol 1,4,5-trisphosphate $\left(\mathrm{IP}_{3}\right)$ receptors are tetrameric intracellular $\mathrm{Ca}^{2+}$ channels, the opening of which is regulated by both $\mathrm{IP}_{3}$ and $\mathrm{Ca}^{2+}$. Taylor and Laude (2007) suggest that all $\mathrm{IP}_{3}$ receptors are biphasically regulated by cytosolic $\mathrm{Ca}^{2+}$, which binds to two distinct sites. According these authors IP $_{3}$ promotes channel opening by controlling whether $\mathrm{Ca}^{2+}$ binds to the stimulatory or inhibitory sites. The stimulatory site is probably an integral part of the receptor lying just upstream of the pore region. Inhibition of $\mathrm{IP}_{3}$ receptors by $\mathrm{Ca}^{2+}$ probably requires an accessory protein, which has not yet been unequivocally identified, but calmodulin is a prime candidate. Taylor and Laude (2007) speculated that one lobe of calmodulin tethers it to the $\mathrm{IP}_{3}$ receptor, while the other lobe can bind $\mathrm{Ca}^{2+}$ and then interact with a second site on the receptor to cause inhibition.

\section{Role of bicarbonate ions and intracellular $\mathrm{pH}$}

It has been shown that the presence of bicarbonate and albumin in capacitation medium in vitro are essential to invoke capacitation (Harrison, 1996). Bicarbonate entering into sperm activates soluble adenylyl cyclase (sAC). This leads to elevated cAMP levels and the activation of protein kinase A (PKA), which either directly or indirectly activates the tyrosine kinase pathway resulting in the phosphorylation of proteins at tyrosine residues. Albumin promotes cholesterol removal from the plasma membrane (Chen et al., 2000; Visconti et al., 2002). On the basis of several publications Iha et al. (2003) summarized the role of bicarbonate ion in capacitation in the following way: 1 . it increases the intracellular $\mathrm{pH}$ during capacitation (Zeng et al., 1996; Cross and Razy-Faulkner, 1997); 2. it increases the intracellular cAMP level by activating soluble adenylyl cyclase; 3 . it induces a rapid and reversible change in the lipid architecture of the sperm plasma membrane; 4. it is involved in the hyperpolarization of sperm plasma membrane, a concomitant phenomenon with capacitation. 
Several experiments have demonstrated (Uguz et al., 1994; Zeng et al., 1996; Cross and Razy-Faulkner, 1997) that during capacitation in vitro the intracellular $\mathrm{pH}$ increases and this could be attributed to the influx of $\mathrm{HCO}_{3}{ }^{-}$during capacitation (Iha et al., 2003). As it has been shown by Demarco et al. (2003) $\mathrm{HCO}_{3}^{-}$regulates the plasma membrane potential inducing a hyperpolarizing current. This hyperpolarization was $\mathrm{Na}+$ dependent suggesting the presence of a $\mathrm{Na}+/ \mathrm{HCO}_{3}^{-}$ co-transporter in sperm; however, a full characterization is still awaited (Demarco et al., 2003).

\section{HYPERACTIVATION}

Capacitation is associated with the development of a distinct motility pattern called hyperactivation, which is characterized by pronounced flagellar movements, marked lateral excursion of the sperm head and a non-linear trajectory (Yanagimachi, 1969, 1970; Suarez and Ho, 2003). Although a relationship between capacitation and hyperactivation has not been clearly documented these two phenomena seem to be regulated by similar transduction events (Brewis et al., 2005). It has been shown that the presence of calcium is required for hyperactivation of hamster (Suarez et al., 1993; Yanagimachi, 1994; Kulanand and Shivaji, 2001), mouse (Fraser, 1987) and bovine spermatozoa (Marquez and Suarez, 2004). Hyperactivation is an energy driven process but recent opinions about the involvement of mitochondrial ATP synthesis in hyperactivation are rather controversial. However, glycolysis has been found to be essential for generating ATP required for hyperactivation of human (Williams and Ford, 2001) and rat (Bone et al., 2000) spermatozoa. It has been proposed for hamster spermatozoa that cAMP might function by maintaining calcium on the optimal level (Aoki et al., 1999). The involvements of cAMP and bicarbonate ions in hyperactivation could be linked by the bicarbonate stimulated synthesis of cAMP, although no direct proof exists for this (Mitra and Shivaji, 2005).

\section{PROTEIN TYROSINE PHOSPHORYLATION AND ACTIN POLYMERIZATION}

As it has been already mentioned, the protein tyrosine phosphorylation event has been found to be dependent on BSA, and other cholesterol acceptors (Visconti et al., 1995; Kulanand and Shivaji, 2001) and can be abolished in presence of tyrosine kinase inhibitors (Bajpai et al., 2003). Almost in all investigated species, immunolocalization studies have indicated that the capacitation dependent tyrosine phosphorylation goes up in the flagella of the spermatozoa (Leclerc et al., 1997; Umer et al., 2001; Iha and Shivaji, 2002). Sperm protein tyrosine phosphorylation is triggered by high levels of cAMP, which regulate protein kinase A - PKA (Umer 
and Sakkas, 2003). As PKA is a serine kinase, intermediate tyrosine kinases or phosphatases have been proposed to be involved in the tyrosine phosphorylation, whose activities could be regulated by PKA. Involvement of protein kinase C (PKC) in this process has been well documented (Breitbart, 2003).

In spermatogenic cells, actin filaments occur in the subacrosomal space between the nucleus and the developing acrosome of spermatids (Vogl, 1989). In mature spermatozoa actin is present both in its monomeric form and as filamentous (F)actin (Howes et al., 2001; Breitbart et al., 2005). It has been reported that actin polymerization is important for initiation of sperm motility during post-testicular maturation (Lin et al., 2002), for sperm incorporation into the egg cytoplasm (Sanchez-Gutierrez et al., 2002) and for sperm nuclei decondensation (Kumakiri et al., 2003). Recently Brener et al. (2003) have shown that actin polymerization occurs during capacitation of mouse, ram, bull and also human sperm, whereas F-actin breakdown should take place in order to achieve the acrosome reaction. Inhibition of actin polymerization blocks sperm penetration in hamster (Rogers et al., 1989), boar (Castellani-Ceresa et al., 1993) and mouse (Brener et al., 2003). It also blocks bovine (Spungin et al., 1995) and human (Liu et al., 1999, 2002) sperm AR.

It is accepted that PKA-dependent tyrosine phosphorylation of several proteins occurs during sperm capacitation (Visconti et al., 1995). As it has been demonstrated by Brener et al. (2003), protein tyrosine phosphorylation and actin polymerization are related processes occurring in bovine and ram sperm capacitation. In bovine sperm, the two processes do not occur in the absence of bicarbonate - both depend on PKA and tyrosine kinase activities, both are enhanced by epidermal growth factor, hydrogen peroxide, and the tyrosine phosphatase inhibitor vanadate, and both are blocked by glucose (Brener et al., 2003). However, these two processes are necessary but insufficient for achieving sperm capacitation when BSA is absent in the incubation medium (Brener et al., 2003; Breitbart et al., 2005). Moreover, inhibition of PKA activity throughout the four hours of sperm capacitation completely blocked actin polymerization, while inhibition of protein kinase $\mathrm{C}$ revealed only partial (40\%) blockade (Cohen et al., 2004). However, the activation of sperm PKC induced rapid PKA-independent actin polymerization (Cohen et al., 2004). The study of Cohen et al. (2004) showed that actin polymerization in bovine sperm is regulated by phospholipase D (PLD) and PLD is activated in sperm by activation of PKA or PKC.

In summary, although PKA or PKC can lead to actin polymerization, a refined balance between the two pathways is required for optimal and sustained activation during sperm capacitation. It appears that PKA promotes capacitation whereas early activation of PKC jeopardizes capacitation. Thus, it would be necessary for inhibition of PKA activity to occur at the end of capacitation in order to achieve PKC activation prior to the acrosome reaction (Breitbart et al., 2005). 


\section{PROTEIN TRANSLATION}

It had been generally accepted that spermatozoa are translationally and transcriptionally silent; however, the latest investigations of Gur and Breitbart (2006) have demonstrated, for the first time, incorporation of labeled amino acids into polypeptides during sperm capacitation. These authors also demonstrated that protein translation in sperm involves mitochondrial but not cytoplasmic ribosomes and that inhibition of protein translation significantly reduced sperm motility, capacitation and in vitro fertilization rate.

The importance of the mitochondrion for pig fertilization has also been shown by El Shourbagy et al. (2006). Their data suggest that mitochondrial number is important for fertilization outcome and embryonic development. Furthermore, a mitochondrial pre-fertilization threshold may ensure that, as mitochondria are diluted out during post-fertilization cleavage, there are sufficient copies of mtDNA per blastomere to allow transmission of mtDNA to each cell of the embryo after the initiation of mtDNA replication during the early postimplantation stages (El Shourbagy et al., 2006).

\section{THE ACROSOME REACTION (AR)}

The most significant change in sperm after capacitation is its ability to undergo the acrosome reaction. Therefore, the acrosome reaction is considered as an assay for capacitation while fertilization is the endpoint of this process. Capacitated spermatozoa exhibit hyperactivation, which is characterized by an increase in flagellar bend amplitude and beat asymmetry (Yanagimachi, 1969, 1970; Ho and Suarez, 2001).

The physiological inducer of capacitation in the female reproductive tract appears to be progesterone. This hormone is present in high concentration in the cumulus surrounding the oocyte and in the follicular fluid, and is capable of inducing acrosome reaction in spermatozoa of several species (Osman et al., 1989; Thomas and Meisel, 1989; Libersky and Boatman, 1995; Senuma et al., 2001). However, the studies of Thérien and Manjunath (2003) on the effect of progesterone on bovine sperm cholesterol efflux, capacitation, and the acrosome reaction have demonstrated a potential role of progesterone in bovine sperm AR but not in capacitation. It is now well established that in bovines the BSP-A1/-A2 proteins (the major proteins of bovine seminal plasma) promote sperm capacitation (Thérien and Manjunath, 2003).

During interaction with the oocyte, spermatozoa are stimulated to undergo acrosomal exocytosis which is a prerequisite for successful fertilization. During this process, lytic enzymes required for sperm binding are released into the extracellular space leading to the fusion of the gametes. Two main agonists of exocytosis have been identified in the oocyte vestments: progesterone (P4) which 
is produced by cumulus cells and zona pellucida glycoprotein, ZP3. Both agonists act together (Roldan et al., 1994; Brewis et al., 2005). Although it is recognized that an influx of extracellular calcium into the sperm cytosol is an absolute obligatory early event in the AR, the actual molecular-signaling mechanisms are still poorly understood. However, significant progress has been achieved in understanding the role of lipid signaling during these events (Roldan, 1998). Stimulation to undergo exocytosis (with P4 or ZP3) leads to activation of phospholipases and subsequen $t$ production of lipid messengers. One early event after stimulation is activation of phosphoinositidase-specific phospholipase C (PLC), followed by activation of phosphatidylcholine (PC)-specific-PLC, which results in the release of various molecular species of diglycerides (Vazquez and Roldan, 1997a,b). Activation of phospholipase $\mathrm{A}_{2}\left(\mathrm{PLA}_{2}\right)$ is another important event during RA - it requires internalization of $\mathrm{Ca}^{2+}$, and leads to hydrolysis of various phospholipids for release of arachidonic acid and other fatty acids and lysolipids, which have an important role in membrane fusion. More information allowing better understanding of the interaction of PLA, P4 and ZP has been presented by Yuan et al. (2003) and Shi et al. (2005). Both P4 and ZP stimulate release of arachidonic acid and lysoPC and decrease of $\mathrm{PC}$ (indicative of $\mathrm{PLA}_{2}$ activation). Inclusion of aristolochic acid (a PLA $\mathrm{PL}_{2}$ inhibitor) abrogated all these lipid changes and visible AR, confirming the importance of lipid changes for exocytosis. Activation of PLA ${ }_{2}$ can also be regulated by other signaling pathways such as cAMP-PKA (Garde and Roldan, 2000; Brewis et al., 2005).

\section{CAPACITATION IN VITRO}

Although capacitation normally occurs in vivo in the female reproductive tract, it may be also mimicked in vitro in defined media, the composition of which is based on the electrolyte composition of oviductal fluid (Yanagimachi, 1994; Moseley et al., 2005). In most cases, capacitation media contain energy substrates, such as pyruvate, lactate and glucose, serum albumin, ions $\mathrm{Ca}^{2+}, \mathrm{K}^{+}$and $\mathrm{Na}^{+}$. With regard to bovine sperm, heparin has been shown to be a remarkably effective component for the promotion of capacitation (Parrish et al., 1988; O'Flaherty et al., 2006). Heparin also appears to be an effective component for caprine sperm capacitation (Kątska-Książkiewicz et al., 2004).

Capacitation of spermatozoa from a number of species can be achieved in vitro in a time-dependent fashion. Under in vitro conditions when capacitation begins it is continued, and some spermatozoa may reach over-capacitation state which means that they undergo a spontaneous acrosome reaction (Yanagimachi, 1994). However, such premature acrosome reaction, leading to acrosome loss, is undesirable, since acrosome-reacted cells are no longer able to fertilize (Yanagimachi, 1994). 
Capacitation is a reversible phenomenon. Treatment of capacitated spermatozoa with specific substances, seminal plasma or by adding decapacitation factor (DF) molecules that can bind to protein receptors on the sperm plasma membrane, decapacitates these cells (Bedford and Chang, 1962). With time, however, the DF will be lost and spermatozoa will again be fertile (Fraser, 1998). These decapacitation factors are found to be associated with the spermatozoa and originate from the seminal fluid and the epididymis (Visconti et al., 1998). The effect of seminal plasma on the in vitro fertilizability of bull spermatozoa has been shown in our study where, for IVF, we used frozen-thawed cauda-epididymal spermatozoa and ejaculated spermatozoa deprived of seminal plasma immediately after collection (Kątska et al., 1996).

The alteration in sperm plasma membrane can be considered as one of the most prominent changes during capacitation and it is primarily brought about by the decrease in cholesterol/phospholipid ratio of the plasma membrane due to the cholesterol efflux. This decrease in cholesterol can be induced by bovine serum albumin (Go and Wolf, 1985; Cross, 1998). Both the commercial BSA preparations and pure recombinant human BSA support the capacitation of sperm exactly in the same way (Bavister et al., 2003). It has been shown that the effect of albumin on the cholesterol content is also dependent on the presence of bicarbonate in the medium (Cross, 1998). The importance of cholesterol removal from sperm plasma membrane was confirmed by observations that cholesterol acceptors such as high density lipoproteins (HDLs) and $\beta$-cyclodextrins mimic the role of BSA and facilitate in vitro capacitation even in the absence of BSA (Choi and Toyoda, 1998; Visconti et al., 1999).

\section{CONCLUSIONS}

The summarized novel findings on regulation of mammalian sperm capacitation are as follows. In uncapacitated spermatozoa, the binding sites on stimulatory $\mathrm{A}_{2 \mathrm{~A}}$ adenosine receptors are available: the binding of adenosine to these receptors or of FPP to its receptor, will activate the receptors, allowing them to interact with stimulatory $\mathrm{G}$ proteins that then activate an $\mathrm{mAC}$ isoform to increase production of cAMP. As capacitation proceeds, the $\mathrm{A}_{2 \mathrm{~A}}$ receptors change conformation and become inactive, while the inhibitory $\mathrm{A}_{1}$ adenosine receptors are activated and can inhibit mAC activity via inhibitory $\mathrm{G}$ proteins. Only one class of calcitonin receptors has been identified, but in uncapacitated cells they appear to interact with stimulatory G proteins to stimulate AC/cAMP and then, in capacitated cells, to interact with inhibitory $\mathrm{G}$ proteins to inhibit AC/cAMP. The consequence of this cAMP inhibition is inhibition of spontaneous acrosome loss but a spermatozoon can still undergo an induced acrosome reaction if it contacts an unfertilized oocyte (Fraser et al., 2006). 
It seems obvious that by better understanding the mechanisms that modulate mammalian sperm function it may be possible to identify problems that could cause infertility and to develop ways to circumvent these problems and, moreover, to develop new, more effective protocols for sperm treatment prior to in vitro fertilization.

\section{REFERENCES}

Adeoya-Osiguwa S.A., Dudley R.K., Hosseini R., Fraser L.R., 1998. FPP modulates mammalian sperm function via TCP-11 and the adenyl cyclase/cAMP pathway. Mol. Reprod. Dev. 51, 468476

Adeoya-Osiguwa S.A., Fraser L.R., 2002. Capacitation state-dependent changes in adenosine receptors and their regulation of adenyl cyclase/cAMP. Mol. Reprod. Dev. 63, 245-255

Adeoya-Osiguwa S.A., Fraser L.R., 2003. Calcitonin acts as a first messenger to regulate adenylyl cyclase/cAMP and mammalian sperm function. Mol. Reprod. Dev. 65, 228-236

Aoki F., Sakai S., Kohmoto K., 1999. Regulation of flagellar bending by cAMP and $\mathrm{Ca}^{2+}$ in hamster sperm. Mol. Reprod. Dev. 53, 77-83

Austin C.R., 1951. Observations of the penetration of the sperm into the mammalian egg. Aust. J. Sci. Res. B 4, 581-596

Bajpai M., Asin S., Doncel G.F., 2003. Effect of tyrosine kinase inhibitors on tyrosine phosphorylation and motility parameters in human sperm. Arch. Andrology 49, 229-246

Bavister B.D., Kinsley D.L., Lane M., Gardner D.K., 2003. Recombinant human albumin supports hamster in vitro fertilization. Hum. Reprod. 18, 113-116

Baxendale R.W., Fraser L.R., 2003. Immunolocalization of multiple $\mathrm{G} \alpha$ subunits in mammalian spermatozoa and additional evidence for Gas. Mol. Reprod. Dev. 65, 384-392

Bedford J.M., Chang M.C., 1962. Removal of decapacitation factor from seminal plasma by high speed centrifugation. Amer. J. Physiol. 202, 179-181

Bendahmane M., Lynch C., Tulsiani D.R.P., 2001. Calmodulin signals capacitation and triggers the antagonist-induced acrosome reaction in mouse spermatozoa. Arch. Biochem. Biophys. 404, $38-47$

Bone W., Jones N.G., Kamp G., Yeung C.H., Cooper T.G., 2000. Effect of ornidazole on fertility of male rats: inhibition of a glycolysis-related motility pattern and zona binding required for fertilization in vitro. J. Reprod. Fertil. 118, 127-135

Breitbart H., Cohen G., Rubinstain S., 2005. Role of actin cytoskeleton in mammalian sperm capacitation and the acrosome reaction. Reproduction 129, 263-268

Brener E., Rubinstein S., Cohen G., Shternall K., Rivlin J., Breitbart H., 2003. Remodeling of the actin cytoskeleton during mammalian sperm capacitation and acrosome reaction. Biol. Reprod. $68,837-845$

Brevis I.A., Van Gestel R.A., Gadella B.M., Jones R., Publicover S.J., Roldan E.R.S., Frayne J., Barratt C.L.R., 2005. The spermatozoon at fertilization: Current understanding and future research directions. Hum. Fertil. 8, 241-251

Brevis I.A., Moore H.D., Frase L.R., Holt W.V., Baldi E., Luconi M., Gadella B.M., Ford W.C.L., Harrison R.A.P., 2005. Molecular mechanism during sperm capacitation. Hum. Fertil. 8, 253261

Calvete J.J., Ensslin M., Mburu J., Iborra A., Martinez P., Adermann K., Waberski D., Sanz L., Töpfer-Petersen E., Weitze K.F., Einarsson S., Rodriguez-Martinez H., 1997. Monoclonal 


\section{MOLECULAR MECHANISMS IN MAMMALIAN SPERM CAPACITATION}

antibodies against boar sperm zona pellucida-binding protein AWN-1. Characterization of a continuous antigenic determinat and immunolocalization of AWN epitopes in inseminated sows. Biol. Reprod. 57, 735-742

Calvete J.J., Mann K., Schafer W., Raida M., Sanz L., Töpfer-Petersen E., 1995a. Boar spermadhesin PSP-II: location of posttranslational modification, heterodimer formation with PSP-I glycoforms and effect of dimerization on the ligand-binding capabilities of the subunits. FEBS Lett. 365, $179-182$

Calvete J.J., Reinert M., Sanz L., Töpfer-Petersen E., 1995b. Effect of glycosylation on the heparinbinding capability of boar and stallion seminal plasma proteins. J. Chromatogr. A 711, 167-173

Calvete J.J., Sanz L., Dostálová Z., Topfer-Petersen E., 1993. Characterization of AWN-1 glycosylated isoforms helps define the zona pellucida and serine proteinase inhibitor-binding region on boar spermadhesins. FEBS Lett. 334, 37-40

Calvete J.J., Sanz L., Dostálová Z., Topfer-Petersen E., 1995c. Spermadhesins: sperm-coating proteins involved in capacitation and zona pellucida binding. Fertelität 11, 35-40

Castellani-Ceresa L., Mattioli M., Radaelli G., Barboni B., Brivio M.F., 1993. Actin polymerization in boar spermatozoa: fertilization is reduced with use of cytochalasin D. Mol. Reprod. Dev. 36, 203-211

Chang M.C., 1951. Fertilizing capacity of spermatozoa deposited in Fallopian tubes. Nature 168, 997-998

Chen Y., Cann M.J., Litvin T.N., Iorgenko V., Sinclair M.L., Levin L.R., Buck J., 2000. Soluble adenylyl cyclase as an evolutionarily conserved bicarbonate sensor. Science 289, 625-628

Choi Y.H., Toyoda Y., 1998. Cyclodextrin removes cholesterol from mouse sperm and induces capacitation in a protein free medium. Biol. Reprod. 59, 1328-1333

Cohen G., Rubinstein S., Gur Y., Breitbart H., 2004. Crosstalk between protein kinase A and C regulates phospholipase D and F-actin formation during sperm capacitation. Develop. Biol. 267, 230-241

Cross N.L., 1998. Role of cholesterol in sperm capacitation. Biol. Reprod. 59, 7-11

Cross N.L., Razy-Faulkner P., 1997. Control of human sperm intracellular pH by cholesterol and its relationship to the response of the acrosome to progesterone. Biol. Reprod. 56, 1169-1174

Darszon A., Beltrán C., Felix R., Nishigaki T., Treviño C.L., 2001. Ion transport in sperm signaling. Develop. Biol. 240, 1-14

Defer N., Best-Belpomme M., Hanoune J., 2000. Tissue specificity and physiological relevance of various isoforms of adenyl cyclase. Amer. J. Physiol. Renal-Physiol. 279, F400-F416

Dostálová Z., Calvete J.J., Sanz L., Töpfer-Petersen E., 1994. Quatitation of boar spermadhesins in accessory sex glands fluids and on the surface of epididymal, ejaculated and capacitated spermatozoa. Biochim. Biophys. Acta 1200, 48-54

de Lamirande E., Leclerc P., Gagnon C., 1997. Capacitation as a regulatory event that primes spermatozoa for the acrosome reaction and fertilization. Mol. Hum. Reprod. 3, 175-194

Demarco I.A., Espinosa F., Edwards J., Sosnik J., De La Vega-Beltran J.L., Hockensmith J.W., Kopf G.S., Darszon A., Visconti P.E., 2003. Involvement of a $\mathrm{Na}+/ \mathrm{HCO}_{3}{ }^{-}$cotransporter in mouse sperm capacitation. J. Biol. Chem. 278, 7001-7009

El Shourbagy S.H., Spikings E.C., Freitas M., St. John J.C., 2006. Mitochondria directly influence fertilisation outcome in the pig. Reproduction 131, 233-245

Espinosa F., López-González I., Munoz-Garay C., Felix R., de la Vega-Beltran J.L., Kopf G.S., Visconti P.E., Darszon A., 2000. Dual regulation of the T-type $\mathrm{Ca}^{+2}$ current by serum albumin and beta-estradiol in mammalian spermatogenic cells. FEBS Lett. 475, 251-256

Felix R., 2005. Molecular physiology and pathology of $\mathrm{Ca}^{+2}$-conducting channels in the plasma membrane of mammalian sperm. Reproduction 129, 251-262 
Ficarro S., Chertihin O., Westbrook V.A., White F., Jayes F., Kalab P., Marto J.A., Shabanowitz J., Herr J.C., Hunt D.F., Visconti P.E., 2003. Phosphoproteome analysis of capacitated human sperm. Evidence of tyrosine phosphorylation of a kinase-anchoring protein 3 and valosincontaining protein/p97 during capacitation. J. Biol. Chem. 278, 11579-11589

Fraser L.R., 1987. Minimum and maximum extracellular $\mathrm{Ca}^{2+}$ requirements during mouse sperm capacitation and fertilization in vitro. J. Reprod. Fertil. 81, 77-89

Fraser L.R., 1998. Interactions between a decapacitation factor and mouse spermatozoa appear to involve fucose residues and GPI-anchored receptor. Mol. Reprod. Dev. 51, 193-202

Fraser L.R., Adeoya-Osiguwa S., Baxendale R.W., 2003. First messenger regulation of capacitation via $G$ protein-coupled mechanisms: a tale of serendipity and discovery. Mol. Hum. Reprod. 9, 739-748

Fraser L.R., Adeoya-Osiguwa S., Baxendale R.W., Gibbons R., 2006. Regulation of mammalian sperm capacitation by endogenous molecules. Front. Biosci. 11, 1636-1645

Fraser L.R., Adeoya-Osiguwa S., Baxendale R.W., Mededovic S., Osiguwa O.O., 2005. First messenger regulation of mammalian sperm function via adenyl cyclase/cAMP. J. Reprod. Dev. $51,37-46$

Fraser L.R., Osiguwa O.O., 2004. Human sperm responses to calcitonin, angiotensin II and FPP in prepared semen samples from normal donors and infertility patients. Hum. Reprod. 19, 596606

Garde J., Roldan E.R.S., 2000. Stimulation of $\mathrm{Ca}^{2+}$-dependent exocytosis of the sperm acrosome by cAMP acting downstream of phospholipase A2. J. Reprod. Fertil. 118, 57-68

Go K.J., Wolf D.P., 1985. Albumin-mediated changes in sperm sterol content during capacitation. Biol. Reprod. 32,145-153

Green C.M., Cockle S.M., Watson P.F., Fraser L.R., 1996. A possible mechanism of action for fertilization promoting peptide, a TRH-related tripeptide that promotes capacitation and fertilizing ability in mammalian spermatozoa. Mol. Reprod. Dev. 45, 244-253

Gur Y., Breitbart H., 2006. Mammalian sperm translate nuclear-encoded proteins by mitochondrialtype ribosomes. Gene. Develop. 20, 411-416

Harrison R.A.P., 1996. Capacitation mechanisms, and the role of capacitation as seen in eutherian mammals. Reprod. Fert. Develop. 8, 581-594

Ho H.C., Suarez S.S., 2001. Hyperactivation of mammalian spermatozoa: function and regulation. Reproduction 122, 519-526

Howes E.A., Hurst S.M., Jones R., 2001. Actin and actin-binding proteins in bovine spermatozoa: potential role in membrane remodeling and intracellular signaling during epididymal maturation and the acrosome reaction. J. Andrology 22, 62-72

Iha K.N., Kameshwari D.B., Shivaji S., 2003. Role of signaling pathways in regulating the capacitation of mammalian spermatozoa. Cell. Mol. Biol. 49, 329-340

Iha K.N., Shivaji S., 2002. Identification of the major tyrosine phosphorylated protein of capacitated hamster spermatozoa as a homologue of mammalian sperm, a kinase anchoring protein. Mol. Reprod. Dev. 61, 258-270

Ito J., Kawano N., Hirabayashi M., Shimada M., 2004. The role of calcium/calmodulin-dependent protein kinase II on the inactivation of MAP kinase and $\mathrm{p} 34^{\mathrm{cdc} 2}$ kinase during fertilization and activation in pig oocytes. Reproduction 128, 409-415

Iwamoto T., Hiroaki H., Furuichi Y., Wada K., Satoh M., Osada T., Gagnon C., 1995. Cloning of boar SPMI gene which is expressed specifically in seminal vesicles and codes for a sperm motility inhibitor protein. FEBS Lett. 368, 420-424

Jagannathan S., Pulicover S.J., Barratt C.L., 2002. Voltage-operated calcium channels in male germ cells. Reproduction 123, 203-215 


\section{MOLECULAR MECHANISMS IN MAMMALIAN SPERM CAPACITATION}

Kątska L., 2000. Molecular events in mammalian sperm capacitation (in Polish). Med. wet. 56, 372-375

Kątska-Książkiewicz L., Ryńska B., Gajda B., Smorąg Z., 2004. Effect of donor stimulation, frozen semen and heparin treatment on the efficiency of in vitro embryo production in goats. Theriogenology 62, 576-586

Kątska L., Ryńska B., Smorag Z., 1996. Effect of seminal plasma on the in vitro fertilizability of bull spermatozoa. Anim. Reprod. Sci. 44, 23-31

Kordan W., Strzeżek J., Fraser L., 2003. Functions of platelet activating factor (PAF) in mammalian reproductive processes: a review. Pol. J. Vet. Sci. 6, 55-60

Kraus M., Ticha M., Zelezna B., Peknicova J., Jonakova V., 2005. Characterization of human seminal plasma proteins homologous to boar AQN spermadhesins. J. Reprod. Immunol. 65, 33-46

Kulanand J., Shivaji S., 2001. Capacitation-associated extracellular $\mathrm{Ca}^{2+}$ requirements during mouse sperm capacitation and fertilization in vitro. Andrologia 33, 95-104

Kumar R., Harper M.J.K., Hanahan D.J., 1988. Occurence of platelet-activating factor in rabbit spermatozoa. Arch. Biochem. Biophys. 260, 497-502

Kumakiri J., Oda S., Kinoshita K., Miyazaki S., 2003. Involvement of Rho family G protein in the cell signaling for sperm incorporation during fertilization of mouse eggs: inhibition by Clostridium difficile toxin B. Develop. Biol. 260, 522-535

Kuzan F.B., Geissler F.T., Henderson W.R., 1990. Role of spermatozoal platelet activating factor in fertilization. Prostaglandins 39, 61-74

Leclerc P., de Lamirande E., Gagnon C., 1997. Regulation of protein-tyrosine phosphorylation and human sperm capacitation by reactive oxygen derivatives. Free Radical Biol. Med. 22, 643-656

Libersky E.A., Boatman D.E., 1995. Effects of progesterone on in vitro sperm capacitation and egg penetration in the golden hamster. Biol. Reprod. 53, 483-487

Lin M., Hess R., Aitken J.R., 2002. Induction of sperm maturation in vitro in epididymal cell cultures of the tammar wallaby (Macropus eugenii): disruption of motility initiation and sperm morphogenesis by inhibition of actin polymerization. Reproduction 124, 107-117

Liu D.Y., Martic M., Clarke G.N., Dunlop M.E., Baker H.W., 1999. An important role of actin polymerization in the human zona pellucida-induced acrosome reaction. Mol. Hum. Reprod. 5, 941-949

Liu D.Y., Martic M., Clarke G.N., Grkovic I., Garrett C., Dunlop M.E., Baker H.W., 2002. An anti-actin monoclonal antibody inhibits the zona pellucida-induced acrosome reaction and hyperactivated motility of human sperm. Mol. Hum. Reprod. 8, 37-47

Marin-Briggiler C.I., Jha K.N., Chertihin O., Buffone G., Herr J.C., Vazquez-Levin M.H., Visconti P.E., 2005. Evidence of the presence of calcium/calmodulin-dependent protein kinase IV in human sperm and its involvement in motility regulation. J. Cell Sci, 118, 2013-2022

Mededovic S., Fraser L.R., 2004. Angiotensin II stimulates cAMP production and protein tyrosine phosphorylation in mouse spermatozoa. Reproduction 127, 601-612

Mededovic S., Fraser L.R., 2005. Mechanisms of action of angiotensin II on mammalian sperm function. Reproduction 129, 211-218

Mitra K., Shivaji S., 2005. Proteins implicated in sperm capacitation. Indian J. Exp. Biol. 43, 1001-1015

Moseley F.L.C., Jha K.N., Björndahl L., Brewis I.A., Publicover S.J., Barratt C.L.R., Lefièvre L., 2005. Protein tyrosine phosphorylation, hyperactivation and progesterone-induced acrosome reaction are enhanced in IVF media: an effect that is not associated with an increase in protein kinase A activation. Mol. Hum. Reprod. 11, 523-529

Nimtz M., Grabenhorst E., Conradt H.S., Sanz L., Calvete J.J., 1999. Structural characterization of the oligosaccharide chains of native and crystallized boar seminal plasma spermadhesin PSP-I and PSP-II glycoforms. Eur. J. Biochem. 265, 703-718 
O'Flaherty C., Beorlegui N., Beconi M.T., 2006. Heparin- and superoxide anion-dependent capacitation of cryopreserved bovine spermatozoa: requirement of dehydrogenases and protein kinases. Free Radical Res. 40, 427-432

Osman R.A., Andria M.L., Jones A.D., Meizel S., 1989. Steroid induced exocytosis: the human sperm acrosome reaction. Biochem. Biophys. Res. Commun. 160, 828-833

Parrish J.J., Susko-Parrish J.L., Winer M.A., First N.L., 1988. Capacitation of bovine sperm by heparin. Biol. Reprod. 38, 1171-1180

Parks J.E., Hough S., Elrod C., 1990. PAF activity in bovine spermatozoa. Biol. Reprod. 43, 806811

Ricker D.D., Minhas B.S., Kumar R., Robertson J.L., Dodson M.G., 1989. The effect of plateletactivating factor on the motility of human spermatozoa. Fert. Steril. 52, 655-658

Rodriguez-Martinez H., Iborra A., Martinez P., Calvete J.J., 1998. Immunoelectron microscopic imaging of spermadhesin AWN epitopes on boar spermatozoa bound in vivo to the zona pellucida. Reprod. Fert. Develop. 10, 491-497

Rogers B.J., Bastias C., Coulson R.L., Russell L.D., 1989. Cytochalasin D inhibits penetration of hamster eggs by guinea pig and human spermatozoa. J. Andrology 10, 275-282

Roldan E.R.S., 1998. Role of phospholipases during sperm acrosomal exocytosis. Front. Biosci. 3, 1109-1119

Roldan E.R.S., Murase T., Shi Q.X., 1994. Exocytosis in spermatozoa in response to progesterone and zona pellucida. Science 266,1578-1581

Roudebush W.E., 2007. Seminal platelet-activating factor. Semin. Thromb. Hemostasis 33, 69-74

Roudebush W.E., Diehl J.R., 2001. Platelet-activating factor content in boar spermatozoa correlates with fertility. Theriogenology 55, 1633-1638

Roudebush W.E., Massey J.B., Elsner C.W., Shapiro D.B., Mitchell-Leef D., Kort H.I., 2005. The significance of platelet-activating factor and fertility in the male primate:a review. J. Med. Primatol. 34, 20-24

Sanchez-Gutierrez M., Contreras R.G., Mujica A., 2002. Cytochalasin-D retards sperm incorporation deep into the egg cytoplasm but not membrane fusion with the egg plasma membrane. Mol. Reprod. Dev. 63, 518-528

Sanz L., Calvette J.J., Jonáková V., Töpfer-Petersen E., 1992. Boar spermadhesin AQN-1 and AWN are sperm-associated acrosin inhibitor acceptor proteins. FEBS Lett. 300, 63-66

Senuma M., Yamano S., Nakagawa K., Irahara M., Kamada M., Aono T., 2001. Progesterone accelerates the onset of capacitation in mouse sperm via T-type calcium channels. Arch. Andrology 47, 127-134

Shi Q.X., Chen W.Y., Yuan Y.Y., Mao L.Z., Yu S.Q., Roldan E.R.S., 2005. Progesterone primes zona pellucida-induced activation of phospholipase $\mathrm{A}_{2}$ during acrosomal exocytosis in guinea pig spermatozoa. J. Cell Physiol. 205, 344-354

Spungin B., Margalit I., Breitbart H., 1995. Sperm exocytosis reconstructed in a cell-free system. Evidence for the involvement of phospholipase $\mathrm{C}$ and actin filaments in membrane fusion. J. Cell Sci. 108, 2525-2535

Suarez S.S., Ho H.C., 2003. Hyperactivated motility in sperm. Reprod. Domest. Anim. 38, 119-124

Suarez S.S., Varosi S.M., Dai X., 1993. Intracellular calcium increases with hyperactivation in intact, moving hamster sperm and oscillates with the flagellar beat cycle. Proc. Nat. Acad. Sci. USA 90, 4660-4664

Taylor C.W., Laude A.J., 2007. IP3 receptors and their regulation by calmodulin and cytosolic $\mathrm{Ca}^{2+}$. Cell Calcium 32, 321-334

Thérien I., Manjunat P., 2003. Effect of progesterone on bovine sperm capacitation and acrosome reaction. Biol. Reprod. 69, 1408-1415 


\section{MOLECULAR MECHANISMS IN MAMMALIAN SPERM CAPACITATION}

Thomas P., Meizel S., 1989. Phosphatidylinositol 4,5-bisphosphate hydrolysis in human sperm stimulated with follicular fluid or progesterone is dependent upon $\mathrm{Ca}^{2+}$ influx. Biochem. J. 264, 539-546

Uguz C., Vredenburgh W.L., Parrish J.J., 1994. Heparin-induced capacitation but not intracellular alkalinization of bovine sperm is inhibited by Rp-adenosine-3',5'/-cyclic monophosphorothioate. Biol. Reprod. 51, 1031-1039

Umer F., Leppens-Luisier G., Sakkas D., 2001. Protein tyrosine phosphorylation in sperm during gamete interaction in the mouse: the influence of glucose. Biol. Reprod. 64, 1350-1357

Umer F., Sakkas D., 2003. Protein phosphorylation in mammalian spermatozoa. Reproduction 125, 17-26

VazquezJ.M., Roldan E.R.S., 1997a. Phospholipid metabolism in boar spermatozoa and role of diacylglycerol species in the de novo formation of phosphatidylcholine. Mol. Reprod. Dev. 47, 105-112

Vazquez J.M., Roldan E.R.S., 1997b. Diacylglycerol species as messengers and substrates for phosphatidylcholine re-synthesis during $\mathrm{Ca}^{+2}$-dependent exocytosis in boar spermatozoa. Mol. Reprod. Dev. 48, 95-105

Visconti P.E., Moore G.D., Bailey J.L., Laclerc P., Connors S.A., Pan D., Olds-Clarke P., Kopf G.S., 1995. Capacitation in mouse spermatozoa. II. Protein tyrosine phosphorylation and capacitation are regulated by a cAMP-dependent pathway. Development 121, 1139-1150

Visconti P.E., Galantino-Homer H., Ning X., Moore G.D., Valenzuela J.P., Jorgez C.J., Alvarez J.G., Kopf G.S., 1999. Cholesterol efflux-mediated signal transduction in mammalian sperm: beta cyclodextrins initiate transmembrane signaling leading to an increase in protein tyrosine phosphorylation and capacitation. J. Biol. Chem. 274, 3235-3242

Visconti P.E., Galantino-Homer H., Moore G.D., Bailey J.L., Ning X., Fornes M., Kopf G.S., 1998. The molecular basis of sperm capacitation. J. Andrology 19, 242-248

Visconti P.E., Westbrook V.A., Chertihin O., Demarco I., Sleight S., Diekman A.B., 2002. Novel signaling pathways in sperm acquisition of fertilizing capacity. J. Reprod. Immunol. 53, 133-150

Vogl A.W., 1989. Distribution and function of organized concentrations of actin filaments in mammalian spermatogenic cells and Sertoli cells. Int. Rev. Cytol. 119, 1-56

Williams A.C., Ford W.C., 2001. The role of glucose in supporting motility and capacitation in human spermatozoa. J. Andrology 22, 680-695

Yanagimachi R., 1969. In vitro capacitation of hamster spermatozoa by follicular fluid. J. Reprod. Fertil. 18, 275-286

Yanagimachi R., 1970. The movement of hamster spermatozoa before and after capacitation. J. Reprod. Fertil. 23, 193-196

Yanagimachi R., 1994. Mammalian fertilization. In: E. Knobil, J.D. Neil (Editors). The Physiology of Reproduction. $2^{\text {nd }}$ Edition. New York, Raven Press, pp. 189-317

Yuan Y.Y., Chen W.Y., Shi Q.X., Mao L.Z., Yu S.Q., Fang X., Roldan E.R.S., 2003. Zona pellucida induces activation of phospholipase A2 during acrosomal exocytosis in guinea pig spermatozoa. Biol. Reprod. 68, 904-913

Zeng Y., Oberdorf J.A., Florman H.M., 1996. pH regulations in mouse sperm: identification of $\mathrm{Na}^{+}-\mathrm{Cl}^{-}$and $\mathrm{HCO}_{3}^{-}$-dependent and arylaminobenzoate-dependent regulatory mechanisms and characterization of their roles in sperm capacitation. Develop. Biol. 173, 510-520

Zeng H.T., Tulsiani D.R.P., 2003. Calmodulin antagonists differentially affect capacitation-associated protein tyrosine phosphorylation of mouse sperm components. J. Cell Sci. 116, 1981-1989

Zhu J., Brackett N.L., Aballa T.C., Lynne C.M., Witt M.W., Kort H.I., Roudebush W.E., 2006a. High seminal platelet-activating factor acetylhydrolase activity in men with spinal cord injuries. J. Andrology 27, 429-433

Zhu J., Massey J.B., Mitchell-Leef D., Elsner C.W., Kort H.I., Roudebush W.E., 2006b. Plateletactivating factor acetylhydrolase activity affects sperm motility and serves as a decapacitation factor. Fert. Steril. 85, 391-394 